\title{
Persepsi Mahasiswa terhadap Penggunaan Virtual Laboratory dalam Pembelajaran Biologi Molekuler
}

\author{
Evi Suryanti ${ }^{1}$, Any Fitriani ${ }^{2}$, Sri Redjeki ${ }^{3}$, dan Riandi ${ }^{4}$ \\ ${ }^{1,2,3,4}$ Program Studi Pendidikan IP A, Sekolah Pascasarjana, Universitas Pendidikan Indonesia, Bandung \\ ${ }^{1}$ Program Studi Pendidikan Biologi, FKIP, Universitas Islam Riau, Pekanbaru \\ e-mail: \\ 1 evisuryanti97@student.upi.edu \\ 2 anyfitriani@yahoo.com \\ ${ }^{3}$ sri.redjeki.n@gmail.com \\ ${ }^{4}$ rian@upi.edu
}

\begin{abstract}
.
Virtual laboratories are developing rapidly in science learning because they have proven to provide significant benefits to the learning process and outcome of science. The limitations of laboratory facilities in learning Molecular Biology at the Biology Education Program in one of the education institutions in Kota Pekanbaru have encouraged the development of virtual PCR applications and the using in learning strategi of modified free inquiry in Molecular Biology on the topic of Polymerase chain reaction (PCR). The purpose of this study is to review students' perceptions of the use of virtual PCR applications and describe and compare these perceptions with the results of previous relevant study. There are five perceptual aspects surveyed, namely innovation, motivation, effectiveness, benefits, and display of practicum procedures. The results of data analysis showed that the highest percentage of positive perceptions was in the aspect of innovation and display of practicum procedures (98\%), followed by motivational (96\%), benefits $(88 \%)$, and effectiveness aspect (86\%). Based on the analysis of results it can be concluded that on average the majority of students (93\%) had a positive perception of the use of virtual PCR in learning Molecular Biology and a small percentage $(7 \%)$ had negative perceptions.
\end{abstract}

Keywords: molecular biology, virtual laboratory, perceptions

\begin{abstract}
ABSTRAK.
Virtual laboratory berkembang pesat penggunaannya dalam pembelajaran sains karena terbukti memberikan manfaat yang signifikan terhadap proses dan hasil belajar sains. Keterbatasan fasilitas laboratorium dalam pembelajaran Biologi Molekuler pada Program Studi Pendidikan Biologi di salah satu LPTK di Kota Pekanbaru telah mendorong pengembangan aplikasi PCR virtual dan penggunaannya dalam pembelajaran Biologi Molekuler berstrategi modified free inquiry pada topik Polymerase chain reaction (PCR). Tujuan penelitian ini untuk meninjau persepsi mahasiswa terhadap penggunaan aplikasi PCR virtual serta mendeskripsikan dan membandingkan persepsi tersebut dengan hasil-hasil penelitian sebelumnya yang relevan. Ada lima aspek persepsi yang disurvei yaitu inovasi, motivasi, efektivitas, manfaat, dan penyajian prosedur praktikum. Hasil analisis data menunjukkan bahwa persentase persepsi positif paling besar adalah pada aspek inovasi dan penyajian prosedur praktikum (98\%), diikuti oleh aspek motivasi (96\%), aspek manfaat (88\%), dan aspek efektivitas (86\%). Berdasarkan hasil analisis data dapat disimpulkan bahwa secara rerata sebagian besar mahasiswa (93\%) mempunyai persepsi positif terhadap penggunaan PCR virtual dalam pembelajaran Biologi Molekuler dan sebagian kecil (7\%) yang memiliki persepsi negatif.
\end{abstract}

Kata kunci: biologi molekuler, virtual laboratory, persepsi 


\section{PENDAHULUAN}

Awal tahun 1980 teknologi komputer mulai merambah dunia pendidikan di sekolah, dan saat itu beberapa peneliti berpendapat bahwa teknologi informasi dan komunikasi (information and communication technology, ICT) akan menjadi bagian penting dari pendidikan untuk generasi mendatang (Brandsford, et al. dalam Bingimlas, 2009). Seiring dengan perkembangan teknologi yang makin pesat, pendapat para peneliti tersebut menjadi kenyataan dengan semakin menguatnya peran komputer dalam dunia pendidikan. Peningkatan peran ICT dalam bidang pendidikan salah satunya didukung oleh kemampuan komputer yang semakin canggih. Berbagai kendala yang dihadapi dalam pembelajaran sains seperti keterbatasan fasilitas laboratorium atau kekurangan sumber belajar dan media pembelajaran dapat diatasi dengan kemampuan teknologi komputer.

Pembelajaran Biologi Molekuler membutuhkan penelaahan, pembahasan, dan prosedur laboratorium yang teliti terhadap berbagai fenomena biologis organisme pada tingkat molekul. Untuk itu diperlukan fasilitas pembelajaran yang mendukung aktivitas mahasiswa dalam menelaah fenomena biologi molekul tersebut. Namun, masih ditemukan kendala keterbatasan fasilitas laboratorium di Program Studi Pendidikan Biologi di salah satu LPTK di Kota Pekanbaru. Alternatif solusi yang dilakukan adalah mengembangkan aplikasi virtual laboratory (virlab) yang diharapkan dapat mengatasi keterbatasan fasilitas laboratorium dan memberikan mahasiswa pengalaman 'bekerja' di laboratorium biologi molekuler.

Virlab adalah simulasi interaktif dari eksperimen di mana semua manipulasi dilakukan di dalam komputer (Špernjak \& Šorgo, 2017). Menurut Abramov, et al. (2016) virlab merupakan suatu software yang mensimulasikan eksperimen di laboratorium nyata. Virlab telah populer digunakan dalam kebanyakan pembelajaran sains, terutama karena didukung oleh peningkatan kemampuan komputer dalam pemrosesan informasi (Špernjak \& Šorgo, 2017). Berbagai aplikasi virlab terkait dengan konten biologi dan juga peralatan biologi virtual telah dikembangkan dan digunakan dalam pembelajaran, misalnya biotechnology virtual labs (Abramov, et al., 2016; Nair, et al., 2012; Diwakar, et al., 2011), virtual microscope (Bonser, et al., 2013; Triola \& Holloway, 2011), virtual transgenic (Shegog, et al., 2012), virtual immunology (Bercot, et al., 2013), virtual morphology laboratory (Avila, et al., 2013), dan dalam bidang mikrobiologi dan toksikologi farmasi (Dyrberg, et al., 2016). Sebagian besar software virlab memiliki grafis 3D yang dapat meningkatkan pengalaman pengguna, namun tingkat detalisasi dari lingkungan virlab bervariasi (Abramov, et al., 2016). Produk software virlab tersedia dalam berbagai platform, termasuk desktop dan web-based. Versi desktop umumnya memiliki grafis yang lebih baik dan kualitas konten yang lebih tinggi (Raineri, 2001).

Penggunaan virlab memiliki beberapa keuntungan, yaitu fleksibel dalam pengaturan waktu dan lokasi praktikum, hasil praktikum langsung tersedia dan dapat diandalkan, praktikum bisa segera diulang, tidak perlu sering membeli peralatan dan bahan laboratorium, eksperimen aman dan hemat karena memungkinkan 'bekerja' dengan bahan berbahaya atau mahal, dan durasi eksperimen menjadi lebih singkat (Špernjak \& Šorgo, 2009); tidak bergantung kepada ketersediaan fasilitas eksperimen yang sebenarnya, minim kesalahan prosedur kerja dan kesalahan penanganan percobaan, dan juga minim penggunaan reagen (Potkonjak, et al., 2016); meningkatkan keselamatan kerja di laboratorium (Toth, et al., 2014); dan merupakan cara yang lebih efektif untuk memfokuskan peserta didik dalam memahami konsep-konsep yang susah (Carnevale dalam Polly, et al., 2014). Adapun keterbatasan atau kelemahan penggunaan virlab dalam pembelajaran adalah hilangnya perolehan hands-on skills dalam bekerja di laboratorium nyata, kurangnya koneksi antara rancangan dan hasil eksperimen, dan tingkat sosialisasi atau kolaborasi di antara siswa menjadi lebih rendah (Špernjak \& Šorgo, 2009); terbatasnya tindakan yang mungkin dilakukan, tanggapan manual yang buruk, dan kemungkinan kurangnya pengalaman yang tepat saat berhadapan dengan fasilitas laboratorium nyata (Potkonjak, et al., 2016). 
Berbagai hasil penelitian telah memaparkan implikasi dari penggunaan virlab dalam pembelajaran sains, misalnya berpotensi untuk meningkatkan persiapan pra-laboratorium sehingga mahasiswa merasa jauh lebih percaya diri dan nyaman mengoperasikan peralatan laboratorium, mampu menyesuaikan parameter dan hasilnya, serta meningkatkan partisipasi diskusi mahasiswa dalam praktikum mikrobiologi dan toksikologi farmasi (Dyrberg, et al., 2016); meningkatkan pengembangan konsep dan keterampilan laboratorium serta kemampuan mendiagnosis penyakit (Polly, et al., 2014); dapat meningkatkan perolehan pengetahuan dan mempromosikan pembelajaran kimia yang efektif, dapat menyajikan materi pengajaran kimia pada tingkat makroskopik, simbolis, dan submikroskopik (Herga, et al., 2016). Penelitian Maldarelli, et al. (2009) menemukan adanya peningkatan yang signifikan dalam jumlah siswa yang mengalami peningkatan pengetahuan, kepercayaan diri, dan pengalaman tentang teknik laboratorium setelah melihat video virlab, dan bahwa video instruksional sebagai latihan pra laboratorium berpotensi untuk membakukan teknik dan mendukung hasil eksperimen yang sukses.

Berdasarkan paparan di atas dapat dinyatakan bahwa virlab memberikan nilai positif dalam pembelajaran biologi atau sains pada umumnya, terutama bagi lembaga pendidikan sains yang masih memiliki keterbatasan fasilitas laboratorium sains. Pengalaman pembelajaran Biologi Molekuler di Program Studi Pendidikan Biologi ini sebelumnya tidak dilengkapi dengan praktikum Biologi Molekuler karena keterbatasan fasilitas laboratorium dan tidak menggunakan virlab, dan pada semester genap Tahun Akademik 2017/2018 telah dilaksanakan pembelajaran Biologi Molekuler dengan pengintegrasian virlab sebagai alternatif solusi bagi keterbatasan fasilitas laboratorium. Dengan demikian tujuan utama penelitian ini adalah untuk mengetahui persepsi mahasiswa terhadap penggunaan virlab dalam pembelajaran Biologi Molekuler khususnya pada topik PCR.

\section{METODOLOGI}

Metode penelitian yang digunakan adalah survei dengan teknik angket untuk menjaring persepsi mahasiswa. Subyek penelitian adalah mahasiswa Pendidikan Biologi di salah satu LPTK di Kota Pekanbaru yang berjumlah 28 orang. Pembelajaran Biologi Molekuler pada topik Polymerase chain reaction (PCR) dilaksanakan dengan strategi modified free inquiry yang mengintegrasikan penggunaan virlab. Angket diisi oleh mahasiswa setelah pembelajaran PCR berakhir. Aplikasi virlab telah dikembangkan dalam suatu penelitian $\mathrm{R} \& \mathrm{D}$ sebelumnya.

Instrumen penelitian berupa angket berskala Likert dirancang terdiri dari aspek inovasi, motivasi, efektivitas, manfaat, dan penyajian prosedur praktikum yang dijabarkan menjadi pernyataan-pernyataan positif dan negatif. Skala pilihan jawaban pada angket terdiri dari 4 skala yaitu 'Sangat Setuju', 'Setuju', 'Kurang Setuju', dan 'Tidak Setuju'. Validasi logis terhadap angket dilakukan oleh dosen-dosen di bidang Pendidikan Biologi, Biologi, dan Biokimia. Kisi-kisi angket dapat dilihat pada Tabel 1:

Tabel 1. Kisi-kisi angket persepsi mahasiswa

\begin{tabular}{|c|c|c|c|c|}
\hline \multirow{2}{*}{ Aspek persepsi } & \multicolumn{2}{|c|}{ Pernyataan } & \multirow{2}{*}{$\begin{array}{c}\text { Nomor } \\
\text { Urut }\end{array}$} & \multirow{2}{*}{$\begin{array}{c}\text { Jumlah } \\
\text { Item }\end{array}$} \\
\hline & Positif & Negatif & & \\
\hline Inovasi & 1 & 1 & 1,2 & 2 \\
\hline Motivasi & 1 & 1 & 3,4 & 2 \\
\hline Efektivitas & 1 & 1 & 5,6 & 2 \\
\hline Manfaat & 1 & 1 & 7,8 & 2 \\
\hline Penyajian prosedur praktikum & 1 & 1 & 9,10 & 2 \\
\hline Total & 5 & 5 & & 10 \\
\hline
\end{tabular}




\section{TEMUAN DAN PEMBAHASAN}

Berdasarkan kisi-kisi tersebut dibuat pernyataan-pernyataan sesuai dengan aspek-aspek persepsi yang telah ditetapkan. Adapun cara penskoran dalam pengolahan data angket yaitu untuk pernyataan positif, skala 'Sangat Setuju' memiliki skor 4, 'Setuju' memiliki skor 3, 'Kurang Setuju' memiliki skor 2, dan 'Tidak Setuju' skornya adalah 1. Sedangkan untuk pernyataan negatif skala 'Sangat Setuju' memiliki skor 1, 'Setuju' memiliki skor 2, 'Kurang Setuju' memiliki skor 3, dan 'Tidak Setuju' memiliki skor 4. Selanjutnya skor yang sama pada setiap pernyataan dihitung dan kemudian dinyatakan dalam persentase mengikuti persamaan berikut:

$$
P=\frac{S}{N} \times 100
$$

dengan:

$\mathrm{P}=$ Persentase tiap skala $(\%)$

$\mathrm{S}=$ Banyaknya skor yang sama

$\mathrm{N}=$ Jumlah responden

Interpretasi persepsi untuk perolehan angka persentase yaitu untuk pernyataan positif persentase dari skala 'Sangat Setuju' (4) dan 'Setuju' (3) dijumlahkan dan diinterpretasikan sebagai persepsi positif, sedangkan persentase dari skala 'Kurang Setuju' (2) dan 'Tidak Setuju' (1) dijumlahkan dan diinterpretasikan sebagai persepsi negatif. Sedangkan untuk pernyataan negatif persentase dari skala 'Sangat Setuju' (1) dan 'Setuju' (2) dijumlahkan dan diinterpretasikan sebagai persepsi negatif, sedangkan persentase dari skala 'Kurang Setuju' (3) dan 'Tidak Setuju' (4) dijumlahkan dan diinterpretasikan sebagai persepsi positif.

Pada awalnya, angket persepsi hanya terdiri dari pernyataan positif, namun validator menyarankan agar ditambahkan pernyataan negatif sebagai penguatan terhadap pernyataan positif dari mahasiswa responden. Kemudian validator juga menyarankan agar beberapa kalimat sebaiknya diperbaiki tata kalimatnya agar lebih mudah dipahami. Setelah diperbaiki maka validator merekomendasikan bahwa angket persepsi dapat digunakan untuk penelitian.

\section{TEMUAN DAN PEMBAHASAN}

Bagian ini akan memaparkan temuan penelitian dan membahasnya dengan cara membandingkan dengan teori atau temuan penelitian yang relevan. Analisis persepsi mahasiswa dilakukan berdasarkan hasil analisis terhadap skor angket yang telah diolah yang secara rinci dapat dilihat pada tabel 2 berikut

Tabel 2. Rekapitulasi persepsi mahasiswa

\begin{tabular}{lccc}
\hline \multirow{2}{*}{ Aspek persepsi } & \multicolumn{2}{c}{ Persentase persepsi $(\%)$} & \multirow{2}{*}{ Jumlah (\%) } \\
\cline { 2 - 3 } & Positif & Negatif & \\
\hline Inovasi & 98 & 2 & 100 \\
\hline Motivasi & 96 & 4 & 100 \\
\hline Efektivitas & 86 & 15 & 101 \\
\hline Manfaat & 88 & 13 & 101 \\
\hline $\begin{array}{l}\text { Penyajian prosedur } \\
\text { praktikum }\end{array}$ & 98 & 2 & 100 \\
\hline Rerata & 93 & 7 & 100 \\
\hline
\end{tabular}


Berdasarkan Tabel 2 dapat dilihat bahwa secara rerata sebagian besar mahasiswa (93\%) mempunyai persepsi positif terhadap penggunaan virlab dalam pembelajaran Biologi Molekuler, dan sebagian kecil $(7 \%)$ memiliki persepsi negatif. Berdasarkan pengamatan terhadap pola konsistensi pilihan jawaban mahasiswa antara pernyataan positif dan negatif, ditemukan ada ketidakkonsistenan jawaban pada semua aspek persepsi. Bahkan pada aspek 'efektivitas' didapati ketidakkonsistenan yang besar. Namun, temuan ini tetap digunakan karena fungsi pernyataan positif dan negatif dalam suatu angket untuk saling memperkuat respon yang diberikan oleh seorang responden.

Tujuan utama dari penelitian ini adalah untuk mengetahui persepsi mahasiswa terhadap penggunaan virlab dalam pembelajaran Biologi Molekuler khususnya pada topik PCR. Persepsi yang positif dari mahasiswa dapat menjadi kontribusi bagi dosen untuk lebih mengembangkan virlab atau media pembelajaran berbasis-komputer lainnya sebagai sumber belajar bagi mahasiswa dan juga dapat mengatasi keterbatasan fasilitas pembelajaran. Uraian selanjutnya akan membahas temuan penelitian dari setiap aspek persepsi mahasiswa terhadap penggunaan PCR virtual, yaitu:

\section{Aspek Inovasi}

Pernyataan 1 dan 2 pada angket meminta mahasiswa untuk memberikan tanggapannya terhadap aspek inovasi (kebaruan) terhadap penggunaan virlab dalam pembelajaran Biologi Molekuler. Sebanyak 98\% mahasiswa berpendapat bahwa penggunaan virlab dalam pembelajaran Biologi Molekuler merupakan pengalaman pertama bagi mereka, sedangkan $2 \%$ mahasiswa berpendapat bahwa virlab sudah sering digunakan oleh dosen yang lain. Temuan ini bermakna bahwa penggunaan virlab merupakan suatu inovasi dalam pembelajaran yang dialami oleh mahasiswa responden sepanjang masa pembelajarannya. Berdasarkan pengamatan terhadap kegiatan laboratorium mahasiswa yang telah berjalan pada matakuliah-matakuliah biologi lainnya di program studi tersebut pada umumnya adalah praktikum riil (wet laboratory) mengikuti panduan praktikum yang disediakan oleh dosen pengampu matakuliah. Untuk kegiatan praktikum yang fasilitas laboratoriumnya belum tersedia, dosen tidak mengadakan praktikum dan meminta mahasiswa untuk mempelajarinya dari sumber-sumber belajar yang tersedia di dunia maya.

Pada saat diperkenalkan istilah virlab mahasiswa terlihat bingung. Persepsi mahasiswa selama ini bahwa kegiatan praktikum hanya dilakukan di suatu ruangan laboratorium atau di alam terbuka. Namun, fakta bahwa praktikum dapat dilakukan pada komputer merupakan pengalaman baru bagi mahasiswa responden, sehingga kebanyakan mereka memiliki persepsi positif terhadap penggunaan virlab. Sejalan dengan hasil penelitian Shegog, et al. (2012) bahwa mahasiswa bersikap positif terhadap penggunaan simulasi komputer dalam mempelajari topik 'Prosedur mengonstruk gen', karena simulasi dapat menyediakan pengalaman belajar yang positif.

Selain itu hasil penelitian Diwakar, et al. (2011) menyatakan bahwa kebanyakan mahasiswa sarjana dan magister menilai positif kehadiran virlab dalam pembelajaran karena dapat meningkatkan pengalaman belajar. Demikian pula Oktaviani, et al. (2016) dalam uji coba terbatas terhadap virlab yang dikembangkannya menemukan bahwa guru dan siswa memberikan tanggapan yang baik pada aspek kesesuaian isi dan kemudahan penggunaan, dan menyimpulkan bahwa virlab yang dikembangkan memiliki validitas tinggi dan layak digunakan dalam pembelajaran.

\section{Aspek Motivasi}

Pernyataan 3 dan 4 untuk aspek motivasi meminta pendapat mahasiswa terkait motivasi mereka terhadap penggunaan virlab dalam pembelajaran materi PCR. Hasil analisis data angket menunjukkan sebanyak 96\% mahasiswa menyatakan termotivasi dan 4\% yang lainnya tidak termotivasi, artinya kebanyakan mahasiswa termotivasi dengan penggunaan virlab. Temuan ini sejalan dengan hasil penelitian Havlíčková, et al. (2018) di mana guru biologi dan calon guru biologi sama-sama termotivasi dengan aktivitas hands-on dan virtual dissection pada subjek Anatomi. 
Berbeda dengan hasil penelitian Špernjak dan Šorgo, (2017) yang menemukan bahwa dari tiga jenis kerja laboratorium, maka virlab paling tidak disukai oleh mahasiswa.

Mahasiswa lebih menyukai computer-supported laboratory (CSL), diikuti oleh traditional laboratory (TL), dan terakhir virtual laboratory (VL) pada percobaan 'Aktivitas ragi, pertukaran gas, dan detak jantung'. Mahasiswa menyukai kerja laboratorium dengan dukungan komputer (CSL), bukan dengan simulasi saja. Mereka lebih menyukai CSL karena ada kombinasi antara aktivitas hands-on dan teknologi komputer sehingga kompetensi hands-on skills dan digital-computer dapat berkembang. Mahasiswa tidak menyukai VL karena segala sesuatunya telah disiapkan dengan sempurna, dan mereka hanya tinggal menekan tombol pada komputer sehingga motivasi menurun dan menjadi bosan.

Aplikasi virlab yang digunakan dalam pembelajaran PCR ini dirancang untuk mendukung pembelajaran free inquiry, di mana mahasiswa harus aktif mencari pengetahuan dan informasi dari berbagai sumber belajar dalam rangka menguji hipotesis penelitian yang telah diajukannya. Oleh karena itu sebelum melakukan kegiatan PCR virtual, mahasiswa harus berusaha mempelajari konsep dan prosedur kerja PCR. Aplikasi PCR virtual menyediakan kesempatan bagi mahasiswa untuk mempersiapkan larutan campuran PCR yang terdiri dari beberapa komponen bahan kimia yang kemudian dimasukkan ke dalam Thermal cycler (mesin PCR) untuk proses amplifikasi. Jadi, pada aplikasi ini mahasiswa tidak hanya menonton simulasi saja, melainkan harus melakukan kegiatan praktikum seolah-olah sedang 'bekerja' di laboratorium riil. Dengan cara seperti ini mahasiswa termotivasi karena ada tantangan untuk bisa mengoperasikan PCR virlab tersebut.

\section{Aspek Efektivitas}

Pernyataan nomor 5 dan 6 pada angket tentang aspek efektivitas virlab dalam menggantikan praktikum PCR yang riil. Hasil analisis data menunjukkan sebanyak $86 \%$ mahasiswa memiliki persepsi positif dan 15\% lainnya negatif. Jika dibandingkan dengan aspek lainnya maka pada aspek efektivitas ini persepsi negatif dari mahasiswa paling besar, artinya cukup banyak mahasiswa yang berpendapat bahwa virlab tidak efektif dan tidak efisien untuk menggantikan praktikum PCR yang riil. Persepsi negatif ini dapat dihubungkan dengan laporan Schnotz dan Lowe (2003) yang menyatakan bahwa penggunaan animasi tidak selalu berfungsi sebagai alat yang efektif untuk pembelajaran.

Pernyataan ini diperkuat oleh hasil penelitian Špernjak dan Šorgo (2017) bahwa mahasiswa pengguna tidak menyukai virlab karena segala sesuatunya telah disiapkan dengan sempurna, dan pengguna hanya tinggal menekan tombol pada komputer sehingga pengguna kurang termotivasi dan menjadi bosan. Demikian juga dengan Smetana dan Bell (2012) yang tidak merekomendasikan virlab sebagai pengganti praktikum hands-on dan CSL, tetapi hanya sebagai pelengkap misalnya untuk pengenalan subjek yang baru, membantu mahasiswa yang tidak hadir, atau untuk mengimplementasikan eksperimen yang mahal, berbahaya atau tidak dapat dipraktikumkan di laboratorium sekolah. Namun, Bakar, et al. (2013) telah menguji efektivitas virlab dengan pendekatan kuasi eksperimen dan hasil pengujian menunjukkan bahwa kelas eksperimen yang menggunakan virlab dalam pembelajarannya memiliki pencapaian akademik yang lebih tinggi dibandingkan dengan kelas kontrol.

\section{Aspek Manfaat}

Pernyataan nomor 7 dan 8 terkait dengan aspek manfaat yang diperoleh dari penggunaan virlab. Sebagian besar mahasiswa $(88 \%)$ memiliki persepsi positif bahwa virtual laboratory PCR dapat memfasilitasi mereka dalam memahami konsep PCR, sedangkan 13\% lainnya menyatakan bahwa praktikum PCR virtual tidak jelas sehingga membingungkan mereka dalam memahami konsep PCR (persepsi negatif). Pada aspek manfaat ini, penggunaan virlab memperoleh persepsi negatif kedua terbesar setelah aspek efektivitas. Menurut peneliti, persepsi negatif dari mahasiswa dapat muncul 
jika mahasiswa tidak bisa menggunakan virlab pada saat pembelajaran karena belum mempunyai persiapan pengetahuan yang cukup. Dalam penerapan strategi pembelajaran free inquiry upaya dan kemandirian mahasiswa sangat dituntut dalam persiapan dan pelaksanaan proses pembelajaran. Dalam artikelnya Yuniarti, et al. (2017) menyatakan bahwa mahasiswa yang memberikan respon positif berarti bisa mengoperasikan dan mensimulasikan eksperimen pengkulturan dan pewarnaan bakteri dengan VL, sehingga membantu mahasiswa dalam memahami materi 'Pengkulturan dan pewarnaan bakteri' dengan mudah.

Banyak artikel hasil penelitian yang membahas tentang manfaat penggunaan media virtual termasuk virlab, misalnya model project based learning berbantuan media virtual berhasil meningkatkan kreativitas peserta didik dalam pembelajaran fisika Gunawan, et al. (2017); keterampilan kerja ilmiah lebih tinggi pada siswa yang belajar dengan guided inquiry berbantuan virlab dibandingkan dengan siswa yang belajar dengan pembelajaran konvensional Juwariyah, et al. (2017); virlab berpotensi untuk meningkatkan persiapan pra-laboratorium sehingga mahasiswa merasa jauh lebih percaya diri dan nyaman mengoperasikan peralatan laboratorium, mampu menyesuaikan parameter dan hasilnya, serta meningkatkan partisipasi diskusi mahasiswa dalam praktikum mikrobiologi dan toksikologi farmasi (Dyrberg, et al. 2016); perolehan pengetahuan dengan menggunakan virlab lebih baik daripada kelas sains tanpa elemen visualisasi (Herga, et al. 2016); intelligent virtual laboratory (IVL) merupakan model yang signifikan untuk meningkatkan pembelajaran mahasiswa (Munawar, et al. 2018); dan lebih dari 80\% mahasiswa yang menggunakan virlab memperoleh nilai ujian yang lebih tinggi dibandingkan dengan kelompok kontrol (Kumar, et al. 2018). Penelitian Alneyadi (2019) menemukankan bahwa virlab memiliki efek yang proporsional terhadap pengetahuan, keterampilan, sikap, prestasi, keterlibatan, motivasi serta inovatif.

\section{Aspek Penyajian Prosedur Praktikum}

Pernyataan nomor 9 dan 10 tentang penyajian atau tampilan prosedur praktikum PCR pada aplikasi virlab. Hasil pengolahan data menunjukkan bahwa $98 \%$ mahasiswa memiliki persepsi positif dan $2 \%$ lainnya negatif. Hal ini bermakna hampir semua mahasiswa berpendapat bahwa prosedur praktikum yang disajikan dalam PCR virtual ringkas, jelas, dan menarik sehingga mudah dipahami. Aspek penyajian atau tampilan dalam suatu virlab merupakan hal penting agar tidak menimbulkan kesalahpahaman dan kebosanan. Tampilan virlab yang jelas, ringkas dan menarik dapat menimbulkan motivasi dan minat sehingga bermanfaat bagi pengguna. Hasil penelitian Polly, et al. (2014) menunjukkan bahwa menurut persepsi mahasiswa Western Blotting $v L A B$ yang dirancang setara dengan real lab sehingga meningkatkan pengembangan konsep, perolehan keterampilan laboratorium dan kemampuan mendiagnosis penyakit. Demikian juga Booth, et al. (2016) menemukan bahwa mayoritas mahasiswa berpendapat bahwa pengalaman belajar dengan $v$ Lab adalah valuable dan format $v$ Lab telah dirancang dengan baik (well-designed).

\section{SIMPULAN}

Berdasarkan analisis data dan pembahasan dapat disimpulkan bahwa secara rerata sebagian besar mahasiswa mempunyai persepsi positif terhadap penggunaan aplikasi virlab dalam pembelajaran Biologi Molekuler, meskipun sebagian kecil mahasiswa berpersepsi negatif. Temuan ini dapat dijadikan dasar untuk lebih mengembangkan aplikasi virlab sebagai salah satu alternatif untuk menciptakan pembelajaran yang lebih menarik, membantu meningkatkan penguasaan konsep, dan mengatasi keterbatasan fasilitas laboratorium. Untuk selanjutnya dapat dilakukan penelitian untuk mengetahui hubungan antara persepsi mahasiswa dengan kemampuan penguasaan konsep PCR dan menganalisis efektivitas penggunaan virlab dalam pembelajaran Biologi Molekuler. 


\section{REFERENSI}

Abramov, V., Kugurakova, V., Rizvanov, A., Abramskiy, M., Manakhov, N., Evstafiev, M., \& Ivanov, D. (2016). Virtual biotechnological lab development. BioNanoScience, 7(2), 363365. doi: https://doi.org/10.1007/s12668-016-0368-9

Alneyadi, S. S. (2019). Virtual lab implementation in science literacy: Emirati science teachers' perspectives. EURASIA Journal of Mathematics, Science and Technology Education, 2019, 15(12), em1786. doi: https://doi.org/10.29333/ejmste/109285

Avila, R. E., Samar, M. E., Sugand, K., Metcalfe, D., Evans, J., \& Abrahams, P. H. (2013). The first South American free online virtual morphology laboratory: Creating history. Creative Education, 4(10A), 6-17. doi: https://doi.org/10.4236/ce.2013.410A002

Bakar, N., Zaman, H. B., Kamalrudin, M., Jusoff, K., \& Khamis, N. (2013). An effective virtual laboratory approach for chemistry. Australian Journal of Basic and Applied Sciences, 7(3), 7884.

Bercot, F. F., Augusto, A., -Neto, F., Lopes, R. M., Faggioni, T., \& Alves, L. A. (2013). Virtual immunology: Software for teaching basic immunology. The International Union of Biochemistry and Molecular Biology, 41(6), 377-383. doi: https://doi.org/10.1002/bmb.20733

Bingimlas, K. A. (2009). Barriers to the successful integration of ICT in teaching and learning environments: A review of the literature. Eurasia Journal of Mathematics, Science \& Technology Education, 5(3), 235-245. doi: https://doi.org/10.12973/ejmste/76803

Bonser, S. P., de Permentier, P., Green, J., Velan, G. M., Adam, P., \& Kumar, R. K. (2013). Engaging students by emphasising botanical concepts over techniques: Innovative practical exercise using virtual microscopy. Journal of Biological Education, 47(2), 123-127. doi: https://doi.org/10.1080/00219266.2013.764344

Booth, C., Cheluvappa, R., Bellinson, Z., Maguire, D., Zimitat, C., Abraham, J., \& Eri, R. (2016). Empirical evaluation of a virtual laboratory approach to teach lactate dehydrogenase enzyme kinetics. Annals of Medicine and Surgery, 8, 6-13. doi: 10.1016/j.amsu.2016.04.019

Diwakar, S., Nair, B. G., \& Nedungadi, P. (2011). Enhanced facilitation of biotechnology education in developing nations via virtual labs: Analysis, implementation and casestudies. International Journal of Computer Theory and Engineering, 3(1), 1793-8201.

Dyrberg, N. R., Treusch, A. H., \& Wiegand, C. (2016). Virtual laboratories in science education: Students' motivation and experiences in two tertiary biology courses. Journal of Biological Education, doi: http://dx.doi.org/10.1080/00219266.2016.1257498

Gunawan, Sahidu, H., Harjono, A., \& Suranti, N. M. Y. (2017). The effect of project-based learning with virtual media assistance on student's creativity in physics. Cakrawala Pendidikan, XXXVI(2), 167-179. doi: 10.21831/cp.v36i2.13514. https://journal.uny.ac.id/index.php/cp/article/view/13514

Havlíčková, V., Šorgo, A., \& Bílek, M. (2018). Can virtual dissection replace traditional hands-on dissection in school biology laboratory work? EURASLA Journal of Mathematics, Science and Technology Education, 14(4), 1415-1429. doi: https://doi.org/10.29333/ jmste/83679

Herga, N. R., Čagran, B., \& Dinevski, D. (2016). Virtual laboratory in the role of dynamic visualisation for better understanding of chemistry in primary school. Eurasia Journal of Mathematics, Science \& Technology Education, 12(3), 593-608. doi: https://doi.org/10.12973/eurasia.2016.1224a

Juwariyah, S., Koes H. S., \& Latifah, E. (2017). Guided inquiry method employing virtual laboratory to improve scientific working skills. Jurnal Pendidikan Sains, 5(1), 17-25. 
Kumar, D., Radhamani, R., Nizar, N., Achuthan, K., Nair, B., \& Diwakar, S. (2018). Virtual and remote laboratories augment self learning and interactions: Development, deployment and assessments with direct and online feedback. doi: https://doi.org/10.7287/peerj.preprints.26715v1

Maldarelli, G. A., Hartmann, E. M., Cummings, P. J., Horner, R. D., Obom, K. M., Shingles, R., \& Pearlman. (2009). Virtual lab demonstrations improve students' mastery of basic biology laboratory techniques. Journal of Microbiology \& Biology Education, 10, 51-57

Munawar, S., Toor, S. K., Aslam, M., \& Hamid, M. (2018). Move to smart learning environment: Exploratory research of challenges in computer laboratory and design intelligent virtual laboratory for e-learning technology. EURASLA Journal of Mathematics, Science and Technology Education, 14(5), 1645-1662. doi: https://doi.org/10.29333/ejmste/85036

Nair, B., Krishnan, R., Nizar, N., Radhamani, R., Rajan, K., Yoosef, A., Sujatha, G., Radhamony, V., Achuthan, K., \& Diwakar, S. (2012). Role of ICT-enabled visualization-oriented virtual laboratories in universities for enhancing biotechnology education - VALUE initiative: Case study and impact. FORMAMENTE, VII(1-2), 209-226.

Oktaviani, E. I., Kadaritna, N., \& Rosilawati, I. (2016). Pengembangan virtual lab untuk praktikum penurunan titik beku dan tekanan osmotik larutan. Jurnal Pendidikan dan Pembelajaran Kimia, 5(2), 203-214

Polly, P., Marcus, N., Maguire, D., Belinson, Z., \& Velan, G. M. (2014). Evaluation of an adaptive virtual laboratory environment using western blotting for diagnosis of disease. BMC Medical Education, 14, 222. doi: https:/ /doi.org/10.1186/1472-6920-14-222

Potkonjak, V., Gardner, M., Callaghan, V., Mattila, P., Guetl, C., Petrovic, V. M., \& Jovanovich, K. (2016). Virtual laboratories for education in science, technology, and engineering: A review. Computers and Education, 95, 309-327. doi: https://doi.org/10.1016/j.compedu.2016.02.002

Raineri, D. (2001). Virtual laboratories enhance traditional undergraduate biology laboratories. Biochemistry and Molecular Biology Education, 29(4), 160-162. doi: https://doi.org/10.1111/j.1539-3429.2001.tb00107.x

Schnotz, W., \& Lowe, R. (2003). External and internal representation in multimedia learning. Learning and Instruction, 13, 117-123. doi: https://doi.org/10.1016/S0959-4752(02)000154

Shegog, R., Lazarus, M. M., Murray, N. G., Diamond, P. M., Sessions, N., \& Zsigmond, E. (2012). Virtual transgenic: Using a molecular biology simulation to impact student academic achievement and attitudes. Res. Sci. Educ., 42, 875-890. doi: https://doi.org/10.1007/s11165-011-9216-7

Smetana, L. K., \& Bell, R. L. (2012). Computer simulations to support science instruction and learning: A critical review of the literature. International Journal of Science Education, 34, 1337-1370. doi: https://doi.org/10.1080/09500693.2011.605182

Špernjak, A., \& Šorgo, A. (2017). Differences in acquired knowledge and attitudes achieved with traditional, computer-supported and virtual laboratory biology laboratory exercises. Journal of Biological Education. doi: https://doi.org/10.1080/00219266.2017.1298532

Špernjak, A., \& Šorgo, A. (2009) Perspectives on the introduction of computer-supported real laboratory exercises into biology teaching in secondary schools: Teachers as part of the problem. In: Lamanauskas V., editor. Challenges of Science, Mathematics, and Technology Teacher Education in Slovenia (Problems of Education in the 21st Century, vol. 14) Siauliai: Scientific Methodological Center Scientia Educologica, 135-143 
Toth, E. E., Ludvico, L. R., \& Morrow, B. L. (2014). Blended inquiry with hands-on and virtual laboratories: The role of perceptual features during knowledge construction. Interactive Learning Environments, 22(5), 614-630. doi: https://doi.org/10.1080/10494820.2012.693102

Triola, M. M., \& Holloway, W. J. (2011). Enhanced virtual microscope for collaborative education. BMC Medical Education, 11, 4. doi: https://doi.org/ 10.1186/1472-6920-11-4

Yuniarti, A., Yeni, L. F., \& Yokhebed. (2017). Development of virtual laboratory based on interactive multimedia on planting and painting bacteria. J. Phys.: Conf. Ser., 895, 012120. https://doi.org/10.1088/1742-6596/895/1/012120 